TOTOBUANG

Volume 5

Halaman 325-339

\title{
DEIKSIS PERSONA BAHASA INDONESIA DIALEK AMBON \\ (Personal Deixes of Indonesian Leanguage With Ambonese Dialect)
}

\author{
Taufik \\ Universitas Hasanuddin \\ Jl. Perintis Kemerdekaan Km. 10, Tamalanrea, Makassar 90245 \\ Pos-el : taufiksalamun@gmail.com
}

(Diterima: 23 November 2017; Direvisi: 24 November 2017; Disetujui: 28 Desember 2017)

\begin{abstract}
Personal deixis of Indonesian language especially in Ambonese dialect are widely use in everyday conversation. This study aimed to describe the forms of personal deixes in Indonesian Leanguage with Ambon Dialect. The research was conducted as a descriptive qualitative study. This type of research is a qualitative descriptive study of objective language phenomena. The data research were oral data obtained from communicative interaction in the Ambon society in the city and its surroundings. The data were collected from people of various ages who used Indonesian language with Ambon dialect. The data were collected using the method of observation with recording and note-taking techniques. The classified data were analysed using the descriptive qualitative method. The results show that the deixes in Indonesian leanguage with Ambon dialect consist of the first singular and plural personal pronoun, second singular and plural pronoun, third singular and plural personal pronoun, and personal pronouns of kinsip lexeme.
\end{abstract}

Keywords: deixis persona, persona pronoun, dialect Indonesia Ambon.

\section{Abstrak}

Deiksis persona bahasa Indonesia dialek ambon banyak digunakan dalam percakapan sehari-hari. Penelitian ini bertujuan mendeskripsikan bentuk-bentuk deiksis persona bahasa Indonesia dialek Ambon. Jenis penelitian ini bersifat deskriptif kualitatif yang mengkaji fenomena kebahasaan yang secara objektif. Data dalam penelitian berupa data lisan yang bersumber dari tindak komunikasi masyarakat kota Ambon dan sekitarnya yang terdiri atas semua rentan usia, yang menggunakan bahasa Indonesia dialek Ambon. Data dikumpulkan menggunakan metode observasi melalui teknik rekam dan catat. Data yang telah diklasifikasi dianalisis secara deskriptif kualitatif. Hasil penelitian menunjukkan bahwa deiksis bahasa Indonesia dialek ambon terdiri atas pronomina persona pertama tunggal dan jamak, pronomina persona kedua tunggal dan jamak, pronomina persona ketiga tunggal dan jamak, dan pronomina persona leksem kekerabatan.

Kata-kata kunci: deiksis persona, pronomina persona, bahasa Indonesia dialek Ambon.

\section{PENDAHULUAN}

Bahasa sebagai alat komunikasi memunyai peranan yang sangat penting dalam interaksi sosial. Ketika seorang pembicara menggunakan bahasa yang tidak dipahami dalam komunikasi, pesan yang disampaikan oleh pembicara tidak akan sampai kepada pendengar. Hal tersebut berlaku juga pada pemilihan kata yang berwujud deiksis karena kata-kata yang deiksis referennya selalu berubah-ubah bergantung pada konteks.

Secara umum, deiksis dalam bahasa Indonesia terdiri atas deiksis persona, deiksis tempat, deiksis waktu, deiksis sosial, dan deiksis wacana. Namun, dari kelima deiksis ini, deiksis personalah yang intensitas kemunculannya dominan pada setiap percakapan. Hal tersebut ditandai dengan jumlah deiksis persona yang lebih banyak daripada deiksis yang lain. Jika dijumlahkan, sebagaimana yang telah diklasifikasikan oleh Purwo (1984) deiksis persona lebih kurang berjumlah 23 termasuk dengan variasinya, yaitu berupa klitika. Belum lagi terdapat kata-kata tertentu yang dapat digunakan sebagai pemarkah deiksis persona, seperti sapaan Bapak, Kakek, dan Adik. Oleh karena itu, pemilihan deiksis persona yang tepat dalam komunikasi sangat penting dilakukan, agar komunikasi dapat terjalin dengan baik. Hal itu termasuk dalam 
penggunaan bahasa Indonesia dialek Ambon yang begitu akrab dipergunakan oleh masyarakat Maluku.

Bahasa Indonesia dialek Ambon disebut juga oleh sebagian orang dengan bahasa Melayu Ambon. Penyebutan tersebut karena bahasa Indonesia dialek Ambon memang berasal dari rumpun bahasa Melayu, sama dengan bahasa Indonesia baku.

Bahasa Indonesia dialek Ambon merupakan bahasa pengantar dan bahasa perdagangan di Provinsi Maluku. Sebagai bahasa pengantar dan bahasa perdagangan, bahasa Indonesia dialek Ambon sangat populer dipergunakan dalam tindak komunikasi. Kepopuleran bahasa Indonesia dialek Ambon dapat dilihat pada frekuensi penggunaannya di masyarakat yang begitu dominan. Anak-anak yang menggunakan bahasa Indonesia baku dalam komunikasi sehari-hari dianggap sok pintar dan sombong. Selain itu, pemerolehan bahasa pertama atau bahasa ibu sebagian besar anak-anak di Maluku adalah bahasa Indonesia dialek Ambon.

Selain itu, suku-suku tertentu ikut memengaruhi perkembangan bahasa Indonesia dialek Ambon. Sebagai contoh, bahasa Indonesia dialek Ambon mendapat pengaruh dari bahasa Indonesia dialek Makassar. Kemudian pada abad ke-16, Portugis menjajah Maluku sehingga cukup banyak kosakata bahasa Portugis masuk ke dalam bahasa Indonesia dialek Ambon. Terakhir, bangsa Belanda masuk juga ke Maluku, yang mengakibatkan cukup banyak kata serapan dari bahasa Belanda yang diterima menjadi kosakata dalam bahasa Indonesia dialek Ambon. Pada zaman Belanda inilah, bahasa Indonesia dialek Ambon dipakai sebagai bahasa pengantar di sekolah-sekolah, di gereja-gereja, dan juga dalam terjemahan dari Alkitab.

Meskipun bahasa Indonesia dialek Ambon mendapat pengaruh dari bahasa Portugis dan Belanda, bahasa Indonesia dialek Ambon bukanlah bahasa yang serumpun dengan kedua bahasa tersebut. Hal itu sejalan dengan yang dikatakan oleh Saimima (dalam Indrayani, 2016) bahwa dialek Indonesia Ambon merupakan bahasa yang tergolong sebagai rumpun atau dialek dari bahasa Melayu standar yang dipertuturkan di wilayah Provinsi Maluku yang mencakup Kota Ambon, Pulau Ambon, Pulau-pulau Lease, yaitu Saparua, Haruku dan Nusa Laut, Pulau Buano, Pulau Manipa, Pulau Kelang, Pulau Seram, Pulau Buru, serta dipakai sebagai bahasa perdagangan atau trade language di Kepulauan Kei, Banda, Kepulauan Watubela, Maluku Tenggara sampai ke Maluku Barat Daya. Sebelum Bangsa Portugis pada tahun 1512 menginjakkan kakinya di Ternate, bahasa Indonesia telah ada di Maluku dan dipergunakan sebagai bahasa perdagangan.

Sebagai bahasa yang banyak mendapatkan pengaruh dari bahasa Portugis dan Belanda, bahasa Indonesia dialek Ambon memiliki beberapa ciri yang berbeda dari dialek bahasa Indonesia yang lain. Ciri khas dari bahasa Indonesia dialek Ambon tersebut salah satunya dalam hal penggunaan kata ganti persona atau deiksis persona. Secara garis besar, penggunaan deiksis persona bahasa Indonesia dialek Ambon sama dengan penggunaan deiksis persona bahasa Indonesia baku yang sama-sama mencakup deksis persona pertama, persona kedua, dan persona ketiga. Hal yang berbeda dari bahasa Indonesia dialek Ambon adalah yang berkaitan dengan bentuk, makna, dan rujukan pada setiap kata yang mengandung pemarkah deiksis. Hal tersebut memungkinkan sebuah kata yang termasuk dalam kategori deiksis persona dalam bahasa Indonesia dialek Ambon, dapat memiliki makna dan acuan yang beragam.

Penjelasan yang telah dipaparkan menunjukkan bahwa deiksis persona yang terdapat pada bahasa Indonesia dialek Ambon sangatlah bervariasi dalam hal rujukan dan makna. Hal tersebut disebabkan oleh aspek sosial kemasyarakatan yang melekat pada deiksis persona bahasa Indonesia dialek Ambon. Artinya, hubungan 
antara seseorang dan orang lain, antara seseorang dan kelompok, atau antara kelompok dan masyarakat dapat terwujud dalam sebuah tindak komuniksi. Agar komunikasi yang terjalin menjadi baik, pilihan kata yang tepat sangatlah penting. Oleh sebab itu, dalam kajian pragmatik ini, dimensi-dimensi sosial akan dilibatkan dalam proses analisis.

Berkaitan dengan hal di atas, penulis mencoba meneliti lebih mendalam lagi penggunaan deiksis yang hanya difokuskan pada deiksis pesona yang dipadukan dengan aspek sosial masyarakat kota Ambon dan sekitarnya. Hal ini dilakukan agar deiksis persona dapat dikaji lebih mendalam, yang tentu saja dengan pertimbangan bahwa bahasa yang digunakan dalam setiap percakapan, selalu memuat penggunaan deiksis persona. Untuk memahami penggunaan bahasa yang bersifat deiksis tersebut, perlu dilakukan suatu kajian. Selain itu, karakteristik penggunaan deiksis persona dalam bahasa Indonesia dialek Ambon sedikit berbeda dengan penggunaan deiksis bahasa yang lain. Untuk maksud tersebut, penelitian ini bertujuan untuk mendeskripsikan deiksis persona bahasa Indonesia dialek Ambon.

\section{LANDASAN TEORI}

Menurut Yule (2014) bentuk linguistik yang dipakai untuk menyelesaikan 'penunjukkan' disebut ungkapan deiksis. Dalam Depdiknas (2014) deiksis diartikan sebagai hal atau fungsi yang menunjuk sesuatu di luar bahasa; kata tunjuk pronomina, ketakrifan, dan sebagainya. Deiksis adalah gejala semantik yang terdapat pada kata atau konstruksi yang hanya dapat ditafsirkan acuannya dengan memperhitungkan situasi pembicaraan. Cummings (2007) menambahkan bahwa deiksis mencakup ungkapan-ungkapan dari kategori-kategori gramatikal yang memiliki keragaman sama banyaknya. Sementara itu, (Usman 2013) mengatakan bahwa deiksis adalah suatu cara untuk mengacu pada hakikat tertentu dengan menggunakan bahasa yang hanya dapat ditafsirkan menurut makna yang diacu oleh penutur dan dipengaruhi situasi pembicaraan

Lebih lanjut, Khayatun (2014) menambahkan bahwa deiksis merupakan kata atau satuan unit linguistik yang rujukan atau maknanya bergantung pada konteks (sosial atau linguistik). Menurut Setyorini (2015) deiksis adalah kata yang tidak memiliki referen yang tetap (tetapi berubahubah) seperti kata saya, sini, sekarang. Misalnya dalam dialog antara A dan B.

A: "saya yang memanggilmu ke sini".

B: "Ada apa memanggil saya? Bicaralah sekarang saya sudah di sini".

Pada contoh di atas deiksis saya secara bergantian mengacu kepada A dan B. Kata sini mengacu kepada tempat yang dekat dengan penutur A dan B, kata sekarang mengacu kepada waktu ketika penutur dan petutur sedang berbicara.

Sejalan dengan contoh di atas, Purwo (1984) menambahkan bahwa sebuah kata dikatakan bersifat deiksis apabila rujukannya berpindah-pindah atau berganti-ganti, bergantung pada siapa yang menjadi pembicara, saat dan tempat dituturkannya kata-kata itu. Kata-kata yang lazim disebut dengan deiksis tersebut berfungsi menunjukkan sesuatu sehingga keberhasilan suatu interaksi antara penutur dan lawan tutur, sedikit banyak akan bergantung pada pemahaman deiksis yang dipergunakan oleh seorang penutur (Nadar, 2009). Deiksis digunakan pula untuk menunjukkan siapa penuturnya, apa yang dimaksud dalam tuturan, dan kapan waktu dalam tuturan tersebut sesuai konteks kalimatnya.

Dalam penelitian ini digunakan istilah deiksis persona yang dikemukakan oleh Yule (2014). Istilah persona berasal dari kata Latin persona sebagai terjemahan dari kata Yunani prosopon, yang artinya topeng (topeng yang dipakai seorang pemain sandiwara), berarti juga peranan atau watak yang dibawakan oleh pemain sandiwara. Istilah persona dipilih oleh ahli bahasa 
waktu itu disebabkan oleh adanya kemiripan antara peristiwa bahasa dan permainan sandiwara (Djajasudarma, 2009). Menurut Syamsurizal, (2015) istilah persona disebut juga pronomina persona atau pronomina orang. Pronomina persona merupakan pronomina yang memunyai kadar kedeiksisan yang tinggi karena mengacu pada orang (dalam hal ini orang merupakan penutur sebagai pusat orientasi deiksis yang menentukan referen yang akan ditunjuk dalam tuturan) (Rahyono, 2011). Pronomina persona juga paling produktif digunakana dalam tuturan. Pronomina persona yang digunakan dalam tuturan menyatakan identitas penutur dan mitra tutur. Setiap bentuk pronomina tersebut menunjukkan status sosial antara si penutur dengan mitra tutur (Rahyono, 2011).

Menurut Sudaryat (2009) deiksis persona merupakan pronomina persona yang bersifat ekstralingual yang berfungsi menggantikan suatu acuan (antesetden) di luar wacana. Dalam kategori deiksis persona yang menjadi kriteria adalah peran/peserta dalam peristiwa berbahasa itu. Deiksis persona juga diartikan sebagai kata yang dipakai untuk mengacu ke nomina lain atau untuk menggantikan nomina lain (Ramaniyar, 2015).

Deiksis persona juga ada yang berbentuk monomorfemik dan polimorfemik. Deiksis yang monomorfemik dibentuk oleh satuan gramatikal yang terdiri atas satu morfem. Deiksis yang polimorfemik dibentuk oleh satuan gramatikal yang terdiri dari dua morfem atau lebih. Polimorfemik dapat dibentuk dari suatu proses morfologis, reduplikasi, dan komposisi atau kata majemuk.

Sehubungan dengan ketepatan pemilihan bentuk deiksis persona, maka harus diperhatikan fungsi bentuk-bentuk pronomina persona. Ada tiga bentuk pronomina persona dalam bahasa Indonesia baku, yaitu (1) pronomina persona pertama tunggal dan jamak, misalnya saya dan kami (2) pronomina persona kedua tunggal dan jamak, misalnya kamu dan kalian (3) pronomina persona ketiga tinggal dan jamak, misalnya dia dan mereka.

\section{METODE PENELITIAN \\ Jenis Penelitian dan Pendekatan}

Penelitian ini merupakan penelitian deskriptif kualitatif. Artinya dalam penelitian ini peneliti mengamati dan melakukan analisis terhadap tuturan masyarakat kota Ambon dan sekitarnya dalam penggunaan deiksis persona bahasa Indonesia dialek Ambon.

Penelitian ini bersifat deskriptif karena mendeskripsikan bentuk deiksis persona bahasa Indonesia dialek Ambon. Selain itu, pendeskripisian data dilakakukan secara objektif dan apaadanya.

\section{Sumber dan Jenis Data}

Sumber data penelitan ini adalah tuturan masyarakat kota Ambon dan sekitarnya yang terdiri atas semua rentan usia (anak-anak, remaja, dewasa, dan orang tua) yang berkomunikasi menggunakan bahasa Indonesia dialek Ambon. Sementara itu, jenis data penelitian ini adalah data lisan, yakni tuturan dengan menggunakan bahasa Indonesia dialek Ambon yang mengandung pemarkah deiksis persona.

\section{Metode dan Teknik Pengumpulan Data}

Metode yang digunakan untuk mengumpulkan data dalam penelitian ini adalah metode observasi. Observasi sendiri diarahkan pada kegiatan berbahasa masyarakat kota Ambon dan seitarnya dengan memperhatikan secara akurat, mencatat fenomena yang terlihat, mempertimbangkan hubungan antaraspek dalam fenomena tersebut dengan mengamati objek kajian dalam konteksnya. Dari metode tersebut, teknik yang dapat digunakan untuk mendukung metode obeservasi yaitu (1) teknik rekam, yaitu teknik yang digunakan untuk merekam peristiwa-peristiwa tutur yang secara potensial banyak mengandung pemarkah deiksis, dengan bantuan alat 
perekam, yakni berupa telepon gengam; (2) teknik catat, yaitu data-data yang telah dikumpulkan melalui teknik rekam selanjutnya dilakukan pencatatan yang kemudian diseleksi berdasarkan jenis-jenis deiksis persona pada kartu data yang telah disiapkan.

\section{Teknik Analisis Data}

Data yang telah diperoleh melalui hasil rekaman, kemudian dianalisis dengan menggunakan metode deskriptif, yaitu penggambaran kenyataan yang ditemukan sebagaimana adanya. Proses analisis dilakukan melalui tahap, mengidentifikasi data deiksis yang ditemukan dalam tuturan masyarakat yang menggunakan bahasa Indonesia dialek Ambon, mengklasifikasikan data berdasarkan permasalahan yang ada, yakni bentukbentuk deiksis pesona. Data yang telah diklasifikasi, selanjutnya diurutkan sesuai dengan tujuan penelitian yang ingin dicapai. Data yang telah diurut tersebut diterjemahkan per glos dan juga dimaknai setiap kalimat. Selanjutnya menganalisis data dengan pendeskripsian secara mendetail permasalahan yang terdapat dalam data yang telah dikumpulkan berdasarkan teori yang berkaitan dengan deiksis persona, yakni dalam hal ini bentuk-bentuk deiksis persona yang meliputi deiksis persona pertama, kedua, ketiga sebagai dasar pedoman analisis. Tahap selanjutnya, yakni menyimpulkan hasil analisis data berdasarkan permasalahan yang ada.

\section{PEMBAHASAN}

Penelitian ini mengungkapkan bahwa penggunaan bentuk-bentuk deiksis persona bahasa Indonesia dialek Ambon, yaitu: (1) pronomina persona pertama tunggal dan jamak, (2) pronomina persona kedua tunggal dan jamak, (3) pronomina persona ketiga tunggal dan jamak, (4) pronomina persona leksem kekerabatan. Selain itu, ditemukan juga struktur posesif pronomina persona pertama, kedua, dan ketiga serta konteks penggunaan deiksis persona bahasa Indonesia dialek Ambon. Pemahaman tentang deiksis persona bahasa Indonesia dialek Ambon akan diuraikan pada pembahasan berikut.

\section{Pronomina Persona Pertama}

Pronomina persona pertama adalah kategorisasi rujukan pembicara kepada dirinya sendiri atau merujuk pada orang yang sedang berbicara.

\section{a. Pronomina Persona Pertama Tunggal}

Pronomina persona pertama tunggal banyak digunakan dalam percakapan bahasa Indonesia dialek Ambon. Untuk pronomina persona pertama tunggal hanya digunakan satu bentuk deiksis, yaitu beta yang bermakna 'saya'. Penggunaan pronomina persona pertama tunggal beta dalam tema percakapan "pemasangan kode wifi" dapat dilihat pada percakapan berikut.

\section{Contoh 1}

Penghuni 1 : (a) Abang,pasang beta wifi do. abang pasang saya wifi dulu 'abang, hubungkan saya dulu wifi'.

Penghuni 2 : (b) Mari $\frac{\text { sini }}{\text { mari }}$.

$$
\text { 'Mari sini'. }
$$

Penghuni 1 : (c) $\frac{\text { Ini }}{\text { ini }} \frac{\text { beta }}{\text { saya }} \frac{H P}{H P}$.

$$
\text { 'Ini HP saya'. }
$$

Penghuni 2 : (d) Oke, su terhubung. oke sudah terhubung 'Oke, sudah terhubung'.

Penghuni 1 : (e) Makasih lai abang. makasih lagi abang 'terimakasih'.

Percakapan terjadi di sebuah rumah kos, yang melibatkan sesama penghuni kos dengan konteks tuturan salah satu penghuni kos meminta untuk menghubungkan kode wifi ke HP-nya. Pada percakapan contoh (1) tampak bahwa adanya penggunaan pronomina persona monomorfemik beta. 
Bentuk pronomina persona beta pada contoh (1) terdapat pada tuturan (a) dan (c) dan merupakan deiksis persona pertama tunggal yang merujuk kepada penutur, yakni dalam hal ini penghuni (1). Penggunaan pronomina persona pertama tunggal beta oleh penghuni (1) dalam pernyataan pada saat dia meminta menghubungkan jaringan wifi ke HP-nya. Pronomina persona pertama tunggal beta pada percakapan contoh (1) tuturan (a) dan (c) bermakna 'seorang penghuni kos yang ingin memasang wifi'.

\section{b. Pronomina Persona Pertama Jamak}

Pronomina persona pertama jamak banyak juga digunakan dalam percakapan bahasa Indonesia dialek Ambon. Untuk pronomina persona pertama tunggal hanya digunakan satu bentuk deiksis, yaitu katong yang bermakna 'kami' dan 'kita'. Penggunaan pronomina persona pertama jamak katong dalam tema percakapan "membuat rencana liburan" dapat dilihat pada percakapan berikut.

Contoh (2)

Pembicara 1 : (a) $\frac{\mathrm{Ha}}{\mathrm{ha}}$, $\frac{\text { kebetulan }}{\text { kebetulan }} \frac{\text { katong }}{\text { kita }} \frac{\text { ada }}{a d a}$ bakumpul, plening abis berkumpul rencana habis lebaran $\underline{\text { di mana? }}$

lebaran di mana

'Ha, kebetulan kita sedang berkumpul, rencana selesai lebaran ke mana'?

Pembicara 2 : (b) iyo batul. 'iya betul'.

Pembicara 3 : (c) loko tar usah lai. mending tidak usah lagi 'lebih baik tidak usah'.

Pembicara $2:$ (d) eh jang ale. eh jangan kamu 'eh jangan kawan'

Percakapan terjadi di sebuah rumah, yang melibatkan sesama teman dengan konteks tuturan seorang teman menanyakan kepada teman yang lain tempat piknik ketika selesai lebaran nanti. Pada percakapan contoh (2) tampak bahwa adanya penggunaan pronomina persona pertama monomorfemik katong.

Bentuk pronomina persona katong pada contoh (2) terdapat pada tuturan (a). Deiksis ini merupakan pronomina persona pertama jamak yang merujuk kepada teman (1) sebagai penutur dan teman yang lain sebagai petutur. Artinya, antara pembicara dan lawan bicara termasuk dalam pronomina persona katong pada contoh (2) ini. Pronomina persona katong pada contoh (2) tuturan (a) merupakan pronomina persona pertama jamak yang bersifat inklusif, karena mencakup orang lain di pihak lawan bicara. Penggunaan pronomina persona pertama jamak katong oleh teman (1) dalam menanyakan kepada teman-temannya tempat untuk berlibur ketika selesai lebaran. Pronomina persona pertama jamak katong pada contoh (2) tuturan (a) ini bermakna 'sesama teman yang membahas rencana tempat untuk berlibur'.

Penggunaan pronomina persona pertama jamak katong dalam tema percakapan "pengalaman makan durian" dapat dilihat pada contoh percakapan berikut.

\section{Contoh (3)}

Teman 1: (a) $\frac{\text { he }}{\text { he }} \frac{\text { Aldin }}{\text { Aldin }} \frac{\text { katong }}{\text { kami }} \underset{\text { pergi }}{\text { per }}$

makang duriang dia bawa tas

makan durian dia bawa tas

badaki, dia tar mau muat

kotor dia tidak mau muat

akang, akhirnya katong yang

itu akhirnya kami yang

sasaran.

sasaran

'Aldin, kami pergi makan

durian dia membawa tas

kotor, dia tidak mau

memuatnya, akhirnya kami

yang kena sasaran'.

Teman 2 : (b) baru tas pung bobou.

baru tas punya berbau

'tas sangat berbau'.

Teman 3 : (c) baru he, baru $\frac{\text { Ide }}{\text { baru }} \frac{\text { dia }}{\text { bale }}$ 
balakang baru ide

belakang baru Ide

$\frac{\text { bilang }}{\text { bilang }} \frac{\text { bagini }}{\text { begini }}$ e, $\frac{\text { hi }}{\text { hi }} \frac{\text { bobou }}{\text { bau }}$.

'terus, kemudian Ide balik ke

belakang, terus Ide berkata

seperti ini, hi bau'.

Percakapan terjadi di sebuah rumah, yang melibatkan sesama teman dengan konteks tuturan menceritakan pengalaman pergi makan durian. Pada percakapan contoh (3) tampak bahwa adanya penggunaan pronomina persona pertama monomorfemik katong.

Bentuk pronomina persona katong pada contoh (3) hanya terdapat pada tuturan (a). Deiksis ini merupakan pronomina persona pertama jamak yang merujuk kepada teman (1) sebagai penutur dan orang lain di pihak teman (1) tersebut. Artinya, lawan bicara dari teman (1) tidak termasuk dalam pronomina persona katong contoh (3) ini. Pronomina persona katong pada contoh (3) tuturan (a) merupakan deiksis persona pertama jamak yang bersifat ekslusif, karena tidak mencakup orang lain di pihak lawan bicara. Penggunaan pronomina persona pertama jamak katong oleh teman (1) dalam pernyataan bahwa dia bersama temannya yang lain pergi untuk mengambil durian, namun tas yang dibawa oleh si Aldin adalah tas yang kotor. Pronomina persona pertama jamak katong pada contoh (3) tuturan (a) ini bermakna 'seorang teman dan orang lain yang berangkat bersamanya pergi ke tempat makan durian.

\section{Pronomina Persona Kedua}

Pronomina persona kedua adalah kategorisasi rujukan pembicara kepada lawan bicara atau dengan kata lain, bentuk pronomina persona kedua baik tunggal maupun jamak merujuk pada lawan bicara.

\section{a. Pronomina Persona Kedua Tunggal}

Pengunaan pronomina persona kedua tunggal juga banyak terdapat dalam percakapan bahasa Indonesia dialek Ambon.
Untuk pronomina persona kedua tunggal digunakan bentuk ose dan ale yang bermakna 'kamu'. Penggunaan pronomina persona kedua tunggal ose yang lain dalam tema percakapan "pembuatan baju angkatan" dapat dilihat pada contoh percakapan berikut.

\section{Contoh (4)}

Teman 1 : (a) $\frac{\text { woe }}{\text { woe }} \frac{\text { katong }}{\text { kita }} \frac{\text { biking }}{\text { buat }} \frac{\text { baju } \text { baju }}{\text { baru }}$ baru 'woe kita buat baju baru'.

Teman 2 : (b) baju lama sa beta minta baju lama saja saya minta $\frac{\text { akang }}{\text { itu }} \frac{\text { beta }}{\text { saya }} \frac{\text { jumawa }}{\text { jengkel }}$ 'baju lama saja, saya minta saya marah'.

Teman 3: (c) baju lama beta seng dapa. baju lama saya tidak dapat 'baju lama saya tidak dapat'

Teman 2 : (d) woe ose itu tu, beta pukul woe kamu itu itu saya pukul ose tu. Ose paleng parlente kamu itu kamu sangat bohong memang. Beta su kirim memang saya sudah kirim $\underline{\text { nomor rekening to }} \underline{\text { su }}$ nomor rekening kan sudah

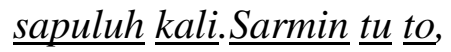
sepuluh kali Sarmin itu kan Sandra pung.

Sandra punya

'kamu itu, saya pukul kamu.

Kamu memang sangat berbohong. Saya kirim no rekening sudah sepuluh kali. Sarmin itu, punya Sandra'.

Percakapan terjadi di sebuah rumah, yang melibatkan sesama teman dengan konteks tuturan membicarakan rencana pembuatan baju baru angkatan. Pada percakapan contoh (4) tampak bahwa adanya penggunaan pronomina persona kedua monomorfemik ose.

Bentuk pronomina persona kedua ose pada contoh (4) terdapat pada tuturan (d). Deiksis ini merupakan pronomina persona kedua tunggal yang merujuk pada teman (3). Penggunaan pronomina persona kedua 
tunggal ose oleh teman (2) dalam pernyataan bahwa dia merasa kesal karena temannya berbohong kepadanya. Pronomina persona kedua tunggal ose pada contoh (4) tuturan (d) ini bermakna 'seorang teman yang sedang dimarahi oleh temannya karena telah berbohong'.

Penggunaan pronomina persona kedua tunggal ale yang lain dalam tema percakapan "meminjam HP" dapat dilihat pada contoh percakapan berikut.

\section{Contoh (5)}

Teman 1: (a) ale, beta lia se $\underline{H P} \underline{\text { do ale. }}$. kamu saya lihat kamu HP dulu kamu 'kawan, saya ligat HP-mu dulu kawan'.

Teman 2 : (b) he $e$. he e.

Teman $1:$ (c) pinjam dolo. pinjam dulu 'pinjam dulu'.

Teman 2 : (d) seng bisa, data-data banya, $\overline{\text { tidak }} \frac{\text { bisa }}{\text { data-data }} \frac{\text { banyak }}{\text { bata-data negara }}$ data-data negara ni ka. data-data negara ini ka

'tidak bisa, bayak data-data, data-data negara'.

Percakapan terjadi di sebuah rumah, yang melibatkan dua orang teman sebaya dengan konteks tuturan seorang teman berkata kepada teman yang lain untuk meminjam HP-nya. Pada percakapan contoh (5) tampak bahwa adanya penggunaan pronomina persona kedua monomorfemik ale.

Bentuk pronomina persona kedua ale pada contoh (5) terdapat pada tuturan (a). Deiksis ini merupakan pronomina persona kedua tunggal yang merujuk pada teman (2). Penggunaan pronomina persona kedua tunggal ale oleh teman (1) dalam pernyataan bahwa dia ingin meminjam HP milik temannya. Pronomina persona kedua tunggal ale pada contoh (5) tuturan (a) bermakna 'teman sebaya yang mau dilihat HP-nya'.

\section{b. Pronomina Persona Kedua Jamak}

Penggunaan pronomina persona kedua jamak juga banyak terdapat dalam percakapan bahasa Indonesia dialek Ambon. Untuk pronomina persona kedua jamak digunakan satu bentuk deiksis, yaitu kamong yang bermakna 'kalian'. Penggunaan pronomina persona kedua jamak kamong dalam tema percakapan "tugas yang ditulis tangan" dapat dilihat pada percakapan berikut.

Contoh (6)

Mahasiswa 1 : (a) kamong ada bae, katong kalian ada baik kami $\underline{\text { tulis }} \underline{\text { tangan }} \underline{\text { ni, }}$ tulis tangan ini satu buku anteru. satu buku penuh 'kalian masih bagus, kami tulis tangan, satu buku penuh'.

Mahasiswa 2 : (b) su abis? sudah habis 'sudah habis'?

Mahasiswa $1:$ (c) balom abis. Saratus belum habis seratus metode pembelajaran, metode pembelajaran baru tulis tangan $\underline{\text { ni. }}$. baru tulis tangan ini 'belum habis. Seratus metode pembelajaran, terus tulis tangan'.

Mahasiawa 3 : (d) mata kuliah apa? mata kuliah apa 'mata kuliah apa'?

Mahasiswa 4 : (e) metode desain $\underline{\text { dan }}$ e.... metode desain dan 'metode desain dan e...'.

Percakapan terjadi di sebuah kampus, yang melibatkan sesama mahasiswa dengan konteks tuturan seorang mahasiswa yang mengeluhkan tugas kampusnya. Pada percakapan contoh (6) tampak bahwa adanya penggunaan pronomina persona kedua monomorfemik kamong. 
Bentuk pronomina persona kedua kamong pada contoh (6) terdapat pada tuturan (a). Deiksis ini merupakan pronomina persona kedua jamak yang merujuk pada orang-orang yang menjadi lawan bicara dari mahasiswa (1). Penggunaan pronomina persona kedua jamak kamong oleh mahasiswa (1) dalam pernyataan bahwa teman-temannya masih mendapatkan tugas yang mudah di bandingkan dengan dirinya. Pronomina persona kedua jamak kamong pada contoh (6) tuturan (a) bermakna 'para mahasiswa yang mendapatkan tugas yang mudah'.

\section{Pronomina Persona Ketiga}

Bentuk pronomina persona ketiga merupakan ketegorisasi rujukan pembicara kepada orang yang berada di luar tindak komunikasi. Hal tersebut berarti bentuk pronomina persona ketiga merujuk pada orang yang tidak berada baik pada pihak pembicara maupun lawan bicara.

\section{a. Pronomina Persona Ketiga Tunggal}

Pronomina persona ketiga tunggal juga banyak digunakan dalam percakapan bahasa Indonesia dialek Ambon. Untuk pronomina persona ketiga tunggal digunakan dua bentuk deiksis, yaitu dia yang tetap bermakna 'dia' dan antua yang bermakna 'beliau'. Penggunaan pronomina persona ketiga tunggal dia dalam tema percakapan "membuka rahasia teman" dapat dilihat pada percakapan berikut.

\section{Contoh (7)}

Teman $1:$ (a) dong dua maing sms saja e, mereka dua main sms saja ya

$\underline{\text { Jang }} \underline{\text { maeng }} \underline{\text { bagitu ale. }}$. jangan main begitu kamu 'mereka berdua bermain sms saja ya. Jangan seperti itu kawan'.

Teman $2:$ (b) barang? karena 'memangnya mengapa'?

Teman 1 : (c) dia nanti kalu di inbox peleng dia nanti kalau di inbox sangat lama, kalu beta seng balas, lama kalau saya tidak balas ale balas dolo ale. kamu balas dulu kamu Dia keadaan bagimana, dia keadaan bagaimana dia $\underline{\text { lai }}$ ni. dia lagi ini

Percakapan terjadi di sebuah rumah. Percakapan tersebut melibatkan sesama teman dengan konteks tuturan seorang teman menceritakan rahasia temannya. Pada percakapan contoh (7) tampak bahwa adanya penggunaan pronomina persona ketiga monomorfemik dia.

Bentuk pronomina persona ketiga dia pada contoh (7) terdapat pada tuturan (c). Deiksis ini merupakan pronomina persona ketiga tunggal yang merujuk kepada seseorang yang sedang dibicarakan dalam percakapan tersebut. Penggunaan pronomina persona ketiga tunggal dia oleh teman (1) dalam pernyataan bahwa pesan yang dikiriminya lama dibalas, namun jika temannya yang mengirimi pesan maka harus segera di balas. Pronomina persona ketiga tunggal dia pada contoh (7) tuturan (c) bermakna 'seseorang yang sedang diceritakan oleh temannya yang tidak terlibat sebagai peserta percakapan dalam percakapan tersebut'.

Penggunaan pronomina persona ketiga tunggal antua dalam tema percakapan "menanyakan ayah" dapat dilihat pada contoh percakapan berikut.

\section{Contoh (8)}

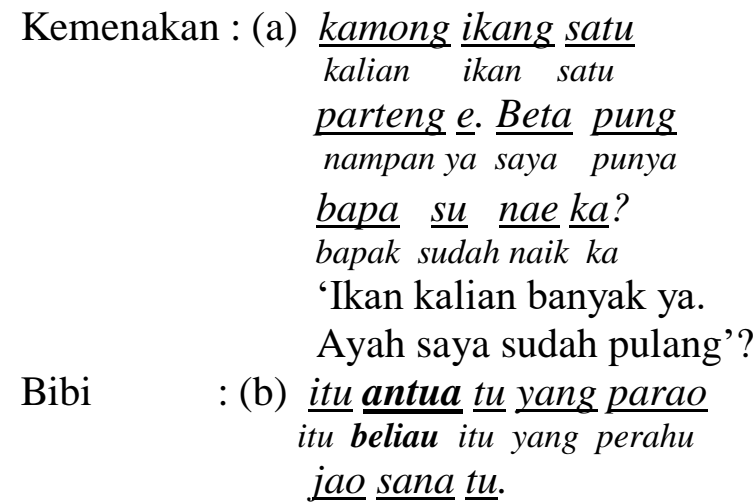


jauh sana itu

'itu beliau yang perahu

jauh di sana'.

Kemenakan : (c) oh itu antua $\underline{\text { e. ho }} \underline{\text { iyo }} \underline{\text { beta }}$ oh itu beliau ya ho iya saya

pi jaga antua jua.

pergi jaga beliau juga

'oh itu beliau. Iya saya pergi

tunggui beliau saja'.

Percakapan terjadi di pinggir pantai, yang melibatkan seorang kemenakan dan bibinya. Percakapan tersebut terjadi dengan konteks tuturan si kemenakan menanyakan ayahnya kepada bibinya. Pada percakapan contoh (8) tampak bahwa adanya penggunaan pronomina persona ketiga monomorfemik antua.

Bentuk pronomina persona ketiga antua pada contoh (8) terdapat pada tuturan (b) dan (c). Deiksis ini merupakan pronomina persona ketiga tunggal yang merujuk kepada seseorang yang sedang ditanyakan oleh si kemenakan kepada bibinya atau merujuk kepada ayah dari si kemenakan tersebut. Penggunaan pronomina persona ketiga tunggal antua oleh si bibi dalam pernyataan bahwa ayah dari kemenakannya itu sudah terlihat dari kejauhan. Sementara itu, penggunaan pronomina persona ketiga tunggal antua oleh si kemenakan dalam pernyataan bahwa dia juga telah melihat ayahnya dan segera akan menunggunya. Pronomina persona ketiga tunggal antua pada contoh (8) tuturan (b) dan (c) bermakna 'saudara dari si bibi' dan juga bermakna 'ayah kandung dari si kemenakan'.

\section{b. Pronomina Persona Ketiga Jamak}

Pengunaan pronomina persona ketiga jamak juga banyak terdapat dalam percakapan bahasa Indonesia dialek Ambon. Untuk pronomina persona ketiga jamak digunakan satu bentuk deiksis, yaitu dong yang bermakna 'mereka'. Penggunaan pronomina persona ketiga jamak dong yang lain dalam tema percakapan "acara pernikahan" dapat dilihat pada contoh percakapan berikut.

\section{Contoh (9)}

Teman 1: (a) itu maksudnya nanti dong itu maksudnya nanti mereka datang kastau baru katong datang beritahu terus kita $\underline{\text { ka sana? }}$ ?

ke sana

'maksudnya itu nanti mereka datang memberitahu, kemudian kita pergi ke sana'?

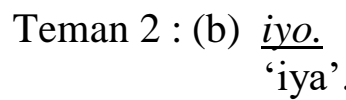

Teman 3 : (c) sapa kas tau? siapa beritahu

'siapa yang beritahu'.

Teman $4:$ (d) pokonya $\frac{\text { nanti }}{\text { pokoknya }} \frac{\text { laki-laki } \frac{\text { yanti }}{\text { laki-laki }} \text { yang }}{\text { lang }}$

$\underline{\text { ka }} \underline{\text { mari }} \underline{\text { to }}$

ke mari kan

'pokoknya nanti pihak

mempelai pria yang ke sini kan'.

Percakapan terjadi di dalam sebuah rumah, yang melibatkan sesama teman. Terjadinya percakapan tersebut dengan konteks tuturan seorang teman mananyakan rangkaian acara pernikahan kepada teman yang lain. Pada percakapan contoh (9) tampak bahwa adanya penggunaan pronomina persona ketiga monomorfemik dong.

Bentuk pronomina persona ketiga dong pada contoh (9) terdapat pada tuturan (a). Deiksis ini merupakan pronomina persona ketiga jamak yang merujuk kepada mempelai pria dan keluarganya yang tidak terlibat sebagai peserta percakapan dalam percakapan tersebut. Penggunaan pronomina persona ketiga jamak dong oleh teman (1) dalam menanyakan bahwa apakah dari keluarga mempelai pria akan datang memberitahu mereka tentang kesiapan mempelai pria. Pronomina persona ketiga jamak dong pada contoh (9) tuturan (a) bermakna 'orang-orang dari pihak mempelai pria'. 


\section{Pronomina Persona Leksem Kekerabatan}

Pengunaan pronomina persona leksem kekerabatan juga banyak terdapat dalam percakapan bahasa Indonesia dialek Ambon. Untuk pronomina persona ketiga jamak digunakan bentuk deiksis kaka, bapa, bapa tua, bapa tenga, bapa bonso, mama. Berikut akan diuraikan satu per satu.

Penggunaan pronomina persona leksem kekerabatan kaka dalam tema percakapan "arah tujuan" dapat dilihat pada percakapan berikut.

\section{Contoh (10)}

Supir $\quad$ : (a) $\frac{\text { kaka }}{\text { kakak }} \frac{\text { terminal }}{\text { terminal }}$ ?
'kakak, mau ke terminal'?
Penumpang: (b) $\frac{\text { iyo, } \frac{\text { Mardika }}{\text { iya }} \frac{\text { to }}{\text { Mardika kan }}}{\text { 'iya, Mardika kan'? }}$
Supir $\quad$ : (c) $\frac{\text { iyo }}{\text { iya } \frac{\text { kaka }}{\text { kakak}}, \frac{\text { mari }}{\text { mari }}} \frac{\text { nae }}{\text { naik }} \frac{\text { suda. }}{\text { sudah }}$
'iya kakak, ayo naik'.

Percakapan terjadi di jalan raya yang melibatkan seorang supir dan seorang calon penumpang. Percakapan tersebut terjadi dengan konteks tuturan si supir menanyakan arah tujuan si calon penumpang. Pada percakapan contoh (10) tampak bahwa adanya penggunaan pronomina persona monomorfemik kaka.

Bentuk pronomina persona kaka pada contoh (10) terdapat pada tuturan (a) dan (c). Deiksis pada percakapan contoh (10) ini merupakan pronomina persona leksem kekerabatan yang merujuk kepada calon penumpang mobil angkutan umum atau angkot. Penggunaan pronomina persona kedua tunggal kaka oleh supir dalam menanyakan apakah si calon penumpang akan pergi ke Terminal Mardika dan segera menyuruh si calon penumpang tersebut untuk naik ke mobil. Pronomina persona kedua tunggal kaka pada contoh (10) tuturan (a) dan (c) bermakna 'seorang calon penumpang'.

Penggunaan pronomina persona leksem kekerabatan bapa tenga dan bapa tua dalam tema percakapan "menanyakan ayah" dapat dilihat pada contoh percakapan berikut.

\section{Contoh (11)}

Anak : (a) bapa tenga lia beta pung bapa? paman lihat saya punya bapak 'paman, lihat ayah saya'?

Paman : (b) seng, barang? tidak karena 'tidak, memangnya ada apa'?

Anak : (c) ada orang di rumah. ada orang di rumah 'ada yang datang di rumah'.

Paman : (d) sapa dong? siapa mereka 'siapa'?

Anak : (e) bapa tua dari Pulo Osi dong. paman dari pulau Osi mereka 'paman dari Pulai Osi'.

Percakapan terjadi di pinggir jalan, yang melibatkan seorang anak dengan pamannya. Konteks tuturan yang terjadi adalah seorang anak menanyakan keberadaan ayahnya kepada pamannya. Pada percakapan contoh (11) tampak bahwa adanya penggunaan pronomina persona polimorfemik bapa tenga dan bapa tua .

Bentuk pronomina persona bapa tenga pada contoh (11) terdapat pada tuturan (a) dan bentuk pronomina persona bapa tua terdapat pada tuturan (e). Deiksis bapa tenga pada percakapan contoh (11) ini merupakan pronomina persona kedua tunggal yang merujuk kepada paman dari si anak yang merupakan lawan tutur pada percakapan tersebut. Penggunaan pronomina persona leksem kekerabatan bapa tenga oleh si anak dalam menanyakan keberadaan ayahnya. Deiksis bapa tua pada percakapan contoh (11) ini merupakan pronomina persona ketiga tunggal yang merujuk kepada paman dari si anak yang sedang di bicararakan atau 
yang tidak terlibat dalam percakapan tersebut. Penggunaan pronomina persona leksem kekerabatan bapa tua oleh si anak dalam pernyataan bahwa keluarganya dari Pulau Osi sedang mengunjungi mereka. Pronomina persona kedua tunggal bapa tenga pada contoh (11) tuturan (a) bermakna 'paman' atau 'saudara laki-laki dari saudara ayah atau ibu si anak yang memiliki kakak dan adik'. Pronomina persona ketiga tunggal bapa tua pada contoh (11) tuturan (e) bermakna 'paman' atau 'saudara laki-laki tertua dari saudara ayah atau ibu si anak'.

Bentuk, kategori, dan makna deiksis persona bahasa Indonesia dialek Ambon dapat dilihat pada tabel berikut ini.

Tabel 1

Rekapitulasi deiksis persona bahasa Indonesia dialek Ambon

\begin{tabular}{|c|c|c|c|c|}
\hline $\begin{array}{l}\text { Deiksis } \\
\text { person } \\
\mathbf{a} \\
\end{array}$ & $\begin{array}{c}\text { Bentuk } \\
\text { deiksis } \\
\text { persona }\end{array}$ & Kategori & Contoh Kalimat & Makna \\
\hline $\begin{array}{c}\text { Beta } \\
\text { (saya) }\end{array}$ & $\begin{array}{c}\text { monomorf } \\
\text { emik }\end{array}$ & $\begin{array}{l}\text { Pronomina } \\
\text { persona } \\
\text { pertama } \\
\text { tunggal }\end{array}$ & $\begin{array}{l}\text { - abang, pasang } \\
\text { beta wifi do. } \\
\text { - iyo e, beta mabo. } \\
\text { - mama beta lai iko. }\end{array}$ & $\begin{array}{l}\text { - Seorang penghuni kos yang } \\
\text { ingin memasang wifi } \\
\text { - Seorang mahasiswa yang } \\
\text { mengeluhkan tugas kampusnya } \\
\text { - Seorang anak kandung }\end{array}$ \\
\hline $\begin{array}{l}\text { Katong } \\
\text { (kita, } \\
\text { kami) }\end{array}$ & $\begin{array}{c}\text { monomorf } \\
\text { emik }\end{array}$ & $\begin{array}{l}\text { Pronomina } \\
\text { persona } \\
\text { pertama } \\
\text { jamak }\end{array}$ & $\begin{array}{l}\text { - kamareng katong } \\
\text { pi di aer panas } \\
\text { to... } \\
\text { - katong mengawas } \\
\quad \text { dari siang sampe } \\
\text { sore? } \\
\text { - he Aldin katong pi } \\
\text { makang duriang } \\
\text { dia bawa tas } \\
\text { badaki... } \\
\text { - ha, kebetulan } \\
\text { katong ada } \\
\text { bakumpul, plening } \\
\end{array}$ & $\begin{array}{l}\text { - Seorang mahasiswa dan orang- } \\
\text { orang yang berangkat } \\
\text { bersamanya pergi ke tempat } \\
\text { permandian air panas'. } \\
\text { - Orang-orang yang terlibat } \\
\text { sebagai pengewas ujian } \\
\text { SBMPTN. } \\
\text { - Seorang teman dan orang lain } \\
\text { yang berangkat bersamanya } \\
\text { pergi ke tempat makan durian. } \\
\text { - Sesama teman yang membahas } \\
\text { rencana tempat untuk berlibur. }\end{array}$ \\
\hline $\begin{array}{c}\text { Ose } \\
(\text { kamu })\end{array}$ & $\begin{array}{c}\text { monomorf } \\
\text { emik }\end{array}$ & $\begin{array}{l}\text { Pronomina } \\
\text { persona } \\
\text { kedua } \\
\text { tunggal }\end{array}$ & $\begin{array}{l}\text { - woe apatempo ose } \\
\text { mau selesaikan itu. } \\
\text { - ose lia ni. } \\
\text { - woe ose itu tu, beta } \\
\quad \text { pukul ose tu. }\end{array}$ & $\begin{array}{l}\text { - teman yang sama-sama } \\
\text { mengerjakan tugas. } \\
\text { - Seorang teman yang sedang } \\
\text { ditunjukkan sebuah topi oleh } \\
\text { temannya. } \\
\text { - Seorang teman yang sedang } \\
\text { dimarahi oleh temannya karena } \\
\text { telah berbohong. }\end{array}$ \\
\hline $\begin{array}{c}\text { Ale } \\
(\text { kamu })\end{array}$ & $\begin{array}{l}\text { monomorf } \\
\text { emik }\end{array}$ & $\begin{array}{l}\text { Pronomina } \\
\text { persona } \\
\text { kedua } \\
\text { tunggal }\end{array}$ & $\begin{array}{l}\text { - ale, se mau kuliah } \\
\text { di mana } \\
\text { - ale, beta pele } \\
\text { bagini se mara ale. } \\
\text { - ale, beta lia se HP } \\
\text { do ale. }\end{array}$ & $\begin{array}{l}\text { - teman sebaya yang menunggu } \\
\text { angkot } \\
\text { - teman sebaya yang dihalangi } \\
\text { pandangannya } \\
\text { - teman sebaya yang mau dilihat } \\
\text { HP-nya' }\end{array}$ \\
\hline
\end{tabular}




\begin{tabular}{|c|c|c|c|c|}
\hline $\begin{array}{l}\text { Kamon } \\
\text { g } \\
\text { (kalian) }\end{array}$ & $\begin{array}{l}\text { monomorf } \\
\text { emik }\end{array}$ & $\begin{array}{l}\text { Pronomina } \\
\text { persona } \\
\text { kedua } \\
\text { jamak }\end{array}$ & $\begin{array}{l}\text { - kamong ada bae, } \\
\text { katong tulis tangan } \\
\text { ni, satu buku } \\
\text { anteru. } \\
\text { - kamong mau } \\
\text { pulang deng ibu? } \\
\text { - abis lebaran } \\
\text { kamong baku } \\
\text { tamba par beta jua }\end{array}$ & $\begin{array}{l}\text { - Para mahasiswa yang } \\
\text { mendapatkan tugas yang mudah. } \\
\text { - dua orang siswa yang latihan } \\
\text { bersama gurunya. } \\
\text { - Orang-orang yang dimintai } \\
\text { untuk berpatungan. }\end{array}$ \\
\hline $\begin{array}{c}\text { Dia } \\
\text { (dia) }\end{array}$ & $\begin{array}{l}\text { monomorf } \\
\text { emik }\end{array}$ & $\begin{array}{l}\text { Pronomina } \\
\text { persona } \\
\text { ketiga } \\
\text { tunggal }\end{array}$ & $\begin{array}{l}\text { - dia nanti kalu di } \\
\text { inbox peleng lama, } \\
\text { kalu beta seng } \\
\text { balas, ale balas } \\
\text { dolo ale... } \\
\text { - iyo, dia baru pinda } \\
\text { tadi pagi... } \\
\text { - ya, dia ada } \\
\text { kaluar... } \\
\end{array}$ & $\begin{array}{l}\text { - Seseorang yang sedang } \\
\text { diceritakan oleh temannya } \\
\text { - Seorang penghuni kos baru. } \\
\text { - Seorang penjual pulsa. }\end{array}$ \\
\hline $\begin{array}{c}\text { Antua } \\
\text { (beliau) }\end{array}$ & $\begin{array}{l}\text { monomorf } \\
\text { emik }\end{array}$ & $\begin{array}{l}\text { Pronomina } \\
\text { persona } \\
\text { ketiga } \\
\text { tunggal }\end{array}$ & $\begin{array}{l}\text { - Aya pung bapa } \\
\text { abis mandi to, beta } \\
\text { topu antua,... } \\
\text { - itu antua tu yang } \\
\text { parao jao sana } \\
\text { tu... } \\
\text { - antua tinggal di } \\
\text { mana? }\end{array}$ & $\begin{array}{l}\text { - Seorang bapak yang disirami } \\
\text { punggungnya. } \\
\text { - Ayah kandung dari si } \\
\text { kemenakan. } \\
\text { - Seorang saudara tertua dari } \\
\text { orang tua si supir. }\end{array}$ \\
\hline $\begin{array}{c}\text { Dong } \\
(\mathrm{mereka})\end{array}$ & $\begin{array}{l}\text { monomorf } \\
\text { emik }\end{array}$ & $\begin{array}{l}\text { Pronomina } \\
\text { persona } \\
\text { ketiga } \\
\text { jamak }\end{array}$ & $\begin{array}{l}\text { - ... Tapi sakarang } \\
\text { dong yang tanya. } \\
\text { - itu maksudnya } \\
\text { nanti dong datang } \\
\text { kastau baru katong } \\
\text { ka sana? } \\
\text { - la barang dong } \\
\text { undang katong } \\
\text { balap... }\end{array}$ & $\begin{array}{l}\text { - Orang-orang yang terlibat dalam } \\
\text { BPJS. } \\
\text { - Orang-orang dari mempelai } \\
\text { pria. } \\
\text { - Orang-orang yang mengajak } \\
\text { anak (1) dan (2) untuk balapan. }\end{array}$ \\
\hline $\begin{array}{c}\text { Kaka } \\
\text { (kakak) }\end{array}$ & $\begin{array}{l}\text { monomorf } \\
\text { emik }\end{array}$ & $\begin{array}{l}\text { Pronomina } \\
\text { persona } \\
\text { kedua } \\
\text { tunggal }\end{array}$ & $\begin{array}{l}\text { - } \text { kaka, terminal? } \\
\text { - tisu kaka, tiga ribu } \\
\text { satu. } \\
\text { - ... kaka ojek? }\end{array}$ & $\begin{array}{l}\text { - Seorang calon penumpang. } \\
\text { - Seorang pembeli. } \\
\text { - Seorang tukang ojek. }\end{array}$ \\
\hline $\begin{array}{c}\text { Bapa } \\
\text { (bapak) }\end{array}$ & $\begin{array}{l}\text { monomorf } \\
\text { emik }\end{array}$ & $\begin{array}{l}\text { Pronomina } \\
\text { persona } \\
\text { kedua } \\
\text { tunggal }\end{array}$ & $\begin{array}{l}\text { - makasih lai bapa. } \\
\text { - bapa, ada jual } \\
\text { kameja tangan } \\
\text { panjang puti. } \\
\text { - tarimakasih bapa. }\end{array}$ & $\begin{array}{l}\text { - Seorang penumpang. } \\
\text { - Seorang penjual. } \\
\text { - Seorang pemilik toko. }\end{array}$ \\
\hline & polimorfe & & & \\
\hline
\end{tabular}




\begin{tabular}{|c|c|c|c|c|}
\hline $\begin{array}{c}\text { Bapa } \\
\text { tua } \\
\text { (paman } \\
\text { ) }\end{array}$ & mik & $\begin{array}{l}\text { Pronomina } \\
\text { persona } \\
\text { ketiga } \\
\text { tunggal }\end{array}$ & $\begin{array}{l}\text { - di beta pung bapa } \\
\text { tua dong. }\end{array}$ & $\begin{array}{l}\text { - Paman atau saudara laki-laki } \\
\text { tertua dari saudara ayah atau } \\
\text { ibu. }\end{array}$ \\
\hline $\begin{array}{c}\text { Bapa } \\
\text { tenga } \\
(\text { paman } \\
\text { ) }\end{array}$ & $\begin{array}{l}\text { polimorfe } \\
\text { mik }\end{array}$ & $\begin{array}{l}\text { Pronomina } \\
\text { persona } \\
\text { kedua } \\
\text { tunggal }\end{array}$ & $\begin{array}{l}\text { - bapa tenga, lia } \\
\text { beta pung bapa. }\end{array}$ & $\begin{array}{l}\text { - Paman atau saudara laki-laki } \\
\text { dari saudara ayah atau ibu yang } \\
\text { memiliki kakak dan adik }\end{array}$ \\
\hline $\begin{array}{c}\text { Bapa } \\
\text { bonso } \\
\text { (paman } \\
\text { ) }\end{array}$ & $\begin{array}{l}\text { polimorfe } \\
\text { mik }\end{array}$ & $\begin{array}{l}\text { Pronomina } \\
\text { persona } \\
\text { ketiga } \\
\text { tunggal }\end{array}$ & $\begin{array}{l}\text { - beta pung bapa } \\
\text { bonso. }\end{array}$ & $\begin{array}{l}\text { - Paman atau saudara laki-laki } \\
\text { terakhir dari saudara ayah atau } \\
\text { ibu. }\end{array}$ \\
\hline $\begin{array}{l}\text { Mama } \\
\text { (mama) }\end{array}$ & $\begin{array}{l}\text { monomorf } \\
\text { emik }\end{array}$ & $\begin{array}{l}\text { Pronomina } \\
\text { persona } \\
\text { kedua } \\
\text { tunggal }\end{array}$ & $\begin{array}{l}\text { - mama, ikang } \\
\quad \text { satampa barapa } \\
\text { ni? } \\
\text { - mama, nasi } \\
\quad \text { padang satu jua. } \\
\text { - mama, ada menu } \\
\text { apa ni? }\end{array}$ & $\begin{array}{l}\text { - Seorang ibu penjual ikan. } \\
\text { - Seorang ibu penjual nasi. } \\
\text { - Seorang ibu kantin. }\end{array}$ \\
\hline
\end{tabular}

Berdasarkan tabel rekapitulasi deksis persona bahasa Indonesia dialek Ambon, dapat dinyatakan bahwa ada satu bentuk deiksis persona pertama tunggal dan jamak yang monomorfemik, ada dua bentuk persona kedua tunggal dan satu bentuk persona kedua jamak yang monomorfemik, ada dua bentuk pronomina persona ketiga tunggal dan satu pronomina persona ketiga jamak monomorfemik, dan ada empat kategori deiksis persona kedua tunggal leksem kekerabatan yang terdiri atas tiga bentuk monomorfemik dan satu bentuk polimorfemik, dua kategori deiksis persona ketiga tunggal yang keduanya merupakan bentuk polimorfemik. Kategori deiksis persona leksem kekerabatan ini dapat berganti-ganti, misalnya deiksis persona mama yang berkategori persona kedua tunggal, dalam konteks tertentu deiksis persona tersebut dapat berkategori persona pertama tunggal atau bisa juga dapat berkategori persona ketiga tunggal.

\section{PENUTUP}

Berdasarkan hasil uraian dan analisis data, dapat disimpulkan beberapa hal yang menjadi temuan dalam penelitian ini.
Temuan tersebut adalah deiksis persona bahasa Indonesia dialek Ambon terdiri atas empat kategori, yaitu (1) satu bentuk pronomina persona pertama tunggal monomofemik dan satu bentuk pronomina persona pertama jamak monomorfemik, (2) dua bentuk pronomina persona kedua tunggal monomorfemik dan satu bentuk pronomina persona kedua jamak monomorfemik, (3) dua bentuk pronomina persona ketiga tunggal monomorfemik dan satu bentuk pronomina persona ketiga jamak monomorfemik, (4) tiga bentuk pronomina persona leksem kekerabatan monomorfemik dan tiga bentuk pronomina persona leksem kekerabatan polimorfemik. Bentuk-bentuk deiksis persona bahasa Indonesia dialek Ambon tersebut memiliki makna dan acuan yang beragam. Hal itu dipengarui oleh siapa yang menjadi pembicara, pendengar, dan dalam konteks tertentu.

\section{DAFTAR PUSTAKA}

Cummings, Louise. 2007. Pragmatik Sebuah Perspektif Multidisipliner. Yogyakarta: Pustaka Pelajar. 
Depdiknas. 2014. KBBI Cetakan ke Delapan Belas Edisi IV. Jakarta: Gramedia Pustaka Utama.

Djajasudarma, Tatimah. 2009. Semantik I (Makna Leksikal dan Gramatikal). Bandung: Refika.

Indrayani, Nanik. 2016. "Penggunaan Bahasa Melayu dialek Ambon dalam Kegiatan Pembelajaran di SMPN Ubung Pulau Buru: Kajian Sosiolinguistik. Makassar: Universitas Hasanuddin.

Khayatun, Nur. 2014. "Deixisverwendung im Drama Der Kaukasische Kreidekreis Von Bertolt Brecht". Jurnal Bahasa dan Sastra Jerman Identitat. Vol. 1, No. 2. Surabaya: Universitas Negeri Surabaya.

Nadar, F.X. 2009. Pragmatik dan Penelitian Pragmatik. Yogyakarta: Graha Ilmu.

Purwo, Bambang Kaswanti. 1984. Deiksis Bahasa Indonesia. Jakarta: Balai Pustaka.

Rahyono, F.X. 2011. Studi Makna. Jakarta: Penaku.

Ramaniayar, Eti. 2015. "Deiksis Bahasa Melayu Dialek Sintang Kecamatan Serawai: Kajian Pragmatik." Jurnal
Pendidikan Bahasa. Vol. 4, No. 2. Pontianak: IKIP PGRI Pontianak.

Setyorini, Nurul. 2015. Analisis Penggunaan

Deiksis Persona dan Deiksis Sosial Novel Akulah Istri Teroris Karya Abidah El Khailaqy. Makalah disajikan dalam seminar Nasional Pertemuan Ilmiah Bahasa dan Sastra Indonesia (PIBSI) XXXVII Asosiasi Deosen Bahasa dan Sastra Indonesia (ADOBSI), Yogyakarta 2-3 Oktober 2015.

Sudaryat, Yayat. 2004. Struktur Makna Prinsip-Prinsip Studi Semantik. Bandung: Raksa Cipta.

Syamsurizal. 2015. "Deiksis dalam Bahasa Pekal di Kabupaten Bengkulu Utara". Jurnal Metalingua. Vol. 13, No. 2. Bengkulu: Kantor Bahasa Provinsi Bengkulu.

Usman, M. 2013. "Deiksis dalam Tuturan Anak Usia 3-5 Tahun". Jurnal Serambi Akademika. Vol. 1, No. 2. Banda Aceh: Universitas Serambi Mekah.

Yule, George. Penerjemah Indah Fajar Wahyuni. 2014. Pragmatik. Yogyakarta: Pustaka Pelajar. 